\title{
MENINGKATKAN HASIL BELAJAR SISWA MELALUI MODEL PEMBELAJARAN INQUIRY DENGAN MENGGUNAKAN METODE EKSPERIMEN PADA POKOK BAHASAN PENCEMARAN LINGKUNGAN KELAS X (PUTRI) TAHUN PELAJARAN 2016/2017
}

\author{
1Suwaibah Al- Islamiyah, ${ }^{2}$ Diah Sudiarti, ${ }^{3}$ Laila Khusnah \\ ${ }_{123}$ Pendidikan Biologi, Universitas Islam Jember \\ 1Suwaibah_alislamiyah@yahoo.co.id,2diah.sudiarti23@gmail.com
}

\begin{abstract}
ABSTRAK
Penelitian merupakan kegiatan utama dari proses pendidikan. Peneliti melakukan penelitian di kelas $X$ (putri) MA Bustanul Ulum Krai-Yosowilangun-Lumajang dengan responden yang diteliti sebanyak 19 siswa Putri. Peneliti melakukan observasi di kelas X (putri) MA Bustanul Ulum Krai-Yosowilangun dan diperoleh data sekitar $75 \%$ menunjukkan nilai siswa $\leq 70$. Prosedur yang digunakan adalah model siklus berdasarkan hasil penelitian, persentase hasil belajar pada siklus I mencapai 38,131 dan siklus II mencapai hingga 44,605 sedangkan untuk melihat persentase hasil belajar siklus I mencapai $68,421 \%$ dan siklus II mencapai 94,736\%.
\end{abstract}

Kata kunci: Hasil belajar, Model pembelajaran inquiry, Metode eksperimen

\section{ABSTRACT}

Learning is a key activity of the educational procces. Researchers conducted in class X (woman) MA Bustanul Ulum Krai-Yosowilangun-Lumajang with responden 19 student woman. Researchers conducted observation in class X(woman) MA Bustanul Ulum Krai-Yosowilangun- Lumajang and approximately $75 \%$ of the data obtained shows student scores $\leq 70$. The procedure used is the model cycle Based on these result, the percentage student result in studyingthe first cycle of 38,131 and second cycle of 44,605 while on the persentage student results in studying first cycle $68,421 \%$ and second cycle of $94,736 \%$. It is proved that the student learning outcomes can be improved with the imlementation of model type inquiry with metode experiment.

Key words: student learning, model type inquiry with metode experiment.

\section{PENDAHULUAN}

Dalam situasi masyarakat yang selalu berubah,idealnya pendidikan tidak hanya berorientasi pada masa lalu dan masa kini, tetapi sudah seharusnya merupakan proses yang mengantisipasi dan membicarakan masa depan. Pendidikan hendaknya melihat jauh ke depan dan memikirkan apa yang akan dihadapi peserta didik dimasa yang akan datang. Menurut Bouchori (dalam Trianto 2007: 1), bahwa pendidikan yang baik adalah pendidikan yang tidak hanya mempersiapkan para siswanya untuk suatu profesi atau jabatan, tetapi untuk menyelesaikan masalah-masalah yang dihadapinya dalam kehidupan sehari-hari

Mata pelajaran yang ada di dalam kurikulum sekarang biasa dikembangkan dengan praktik nyata dalam kehidupan masyarakat. Misalnya, pada mata pelajaran Biologi. Materi Biologi adalah materi yang berkaitan dengan cara mencari tahu dan memahami alam secara sistematis, 
sehingga belajar bukan hanya penyesuaian kumpulan-kumpulan pengetahuan yang berupa fakta-fakta, konsep-konsep, prinsip-prinsip saja tetapi merupakan suatu proses penemuan. Pendidikan biologi diharapkan dapat menjadi wahana bagi siswa untuk mempelajari dirinya sendiri dan alam sekitarnya.

Dalam setiap proses belajar mengajar khususnya dalam pembelajaraan biologi, guru harus memiliki strategi mengajar agar siswa dapat belajar secara efektif dan efisien. Strategi yang menumbuhkan keberhasilan siswa dalam belajar erat kaitannya dengan metode mengajar yang dipakai guru. Salah satu strategi belajar yang memperhatikan kemampuan peserta didik dan hakekat biologi yang berorientasi pada pandangan konstruktivisme adalah belajar kooperatif

Belajar adalah suatu proses perubahan tingkah laku individu yang mengakibatkan bertambahnya pengetahuan, keterampilan dan nilai sikap yang diperoleh melalui interaksi individu dengan lingkungannya. Hasil belajar adalah kemampuan yang diperoleh anak setelah melalui kegiatan belajar atau penguasaan pengetahuan atau keterampilan yang dikembangkan oleh mata pelajaran yang biasanya ditunjukkan dengan nilai tes atau angka nilai yang diberikan guru (Bruner 1998)

Hasil belajar di Sekolah adalah nilai perolehan siswa sementara mata pelajaran tertentu yang dikenal sebagai "prestasi belajar." Sejalan dengan itu, (Nasution 1990) mengatakan bahwa prestasi belajar biologi adalah hasil belajar dari satu individu tersebut berinteraksi secara aktif dan pasif dengan lingkungannya. Pendapat lain yang dikemukakan (Winkel 1991) bahwa prestasi belajar yang dihasilkan oleh siswa menghasilkan perubahan-perubahan dalam bidang pengetahuan/pengalaman dalam bidang keterampilan, nilai dan sikap (Maslow, 1994: 59-62).

Permasalahan yang terjadi bahwa siswa di MA Bustanul Ulum Krai Yosowilangun, disini guru hanya menggunakan metode ceramah, mecatat dan memberikan tugas sehingga siswa bosan dan mengantuk dalam proses KBM (Kegiatan Belajar Mengajar) yang berlangsung, hasil belajarnya juga kurang baik dan kurang maksimal dengan nilai KKM di bawah 75 yaitu $70 \%$. Model pembelajaran inquiry dengan metode eksperimen adalah model pembelajaran yang melibatkan siswa dalam kehidupan yang nyata sehingga siswa mudah mengingat apa yang dilakukan waktu melakukan percobaan/bereksperimen.

\section{METODE PENELITIAN}

Penelitian ini menggunakan desain Penelitian Tindakan Kelas (PTK). Indikator keberhasilan pada penelitian ini dapat diukur dengan adanya peningkatan hasil belajar siswa dari hasil tes saat kegiatan belajar mengajar selesai, dimana sebesar $75 \%$ siswa telah mencapai nilai sesuai KKM yang telah ditentukan yakni 75 .

Dalam penelitian ini metode pengumpulan data yang digunakan adalah sebagai berikut:

a.Wawancara

Metode wawancara ditunjukkan kepada guru dan beberapa siswa dalam bentuk tanya jawab mengenai bagaimana 
cara guru mengajar selama didalam kelas serta hasil belajar untuk informasi yang dibutuhnkan peneliti dan mendapatkan keterangan-keterangan lisan melalui percakapan dan tatap muka dengan orang yang dapat memberikan keterangan pada peneliti.

b.Observasi

Observasi merupakan teknik pengumpulan data, dimana peneliti melakukan pengamatan secara langsung ke objek penelitian untuk melihat dari dekat kegiatan yang dilakukan.

c.Metode Dokumentasi

Metode dokumentasi yaitu pengumpulan data dimana peneliti menyelidiki hasil belajar siswa

d.Tes

Tes adalah alat untuk memperoleh data tentang perilaku individu yang didalamnya terdapat sekumpulan pertanyaan yang harus dijawab oleh siswa sendiri.

Unuk mengetahui peningkatan hasil belajar siswa digunakan rumus:

$$
\mathrm{X}=\frac{\Sigma X}{N}
$$

Keterangan :

${ }^{-} \mathrm{X}=$ Nilai rata-rata Hasil belajar siswa

$\sum X=$ Jumlah seluruh skor

$\mathrm{N}=$ Banyaknya siswa

Sumber: Sudjana, 2009 (dalam Yeni 2012)

Untuk mengetahui ketuntasan hasil belajar siswa digunakan rumus

$$
P=\frac{\sum^{N i}}{\Sigma^{N}} \times 100 \%
$$

\section{Keterangan:}

$\mathrm{P}=$ Persentase ketuntasan hasil belajar siswa

$$
\begin{aligned}
& \sum \mathrm{Ni}=\text { Jumlah siswa yang tuntas }(\geq 75) \\
& \sum \mathrm{N}=\text { Jumlah siswa }
\end{aligned}
$$

\section{HASIL DAN PEMBAHASAN}

Berdasarkan hasil penelitian pada siklus I menunjukan bahwa dari 19 siswa, ada beberapa siswa yang tidak memahami konsep dari pembelajaran inquiry dengan metode eksperimen sehingga belum mencapai ketuntasan klasikal. Pada siklus II siswa sudah memahami konsep pembelajaran inquiry dengan metode eksperimen, hal ini dapat dilihat pada hasil belajarnya. Saat proses belajar mengajar berlangsung, siswa sangat antusias dan senang meski terjadi sedikit kegaduhan, tetapi rata-rata siswa melakukan pembelajaran dengan baik dan banyak siswa yang berani menyampaikan pendapat. Dengan menggunakan penerapan model pembelajaran inquiry dengan metode eksperimen dapat menciptakan pembelajaran yang menarik dan bermakna sehingga siswa termotivasi untuk belajar dan tidak bosan dalam mengikuti pembelajaran serta dapat berfikir kritis, sehingga merangsang perkembangan kreatifitas siswa. Selain itu, model pembelajaran inquiry dengan metode eksperimen membuat siswa lebih memahami materi yang mereka pelajari, karena pembelajaran lebih menarik dan siswa di sini harus bisa membangun konsep tentang sub pokok bahasan Pencemaran dan Perubahan Lingkungan, 
sehingga tercipta pembelajaran yang bermakna bagi siswa.

Model pembelajaran inquiry dengan metode eksperimen ini sangat berhasil dalam meningkatkan hasil belajar siswa di kelas X(Putri) di MA Bustanul Ulum Krai Yosowilangun. Hal ini terlihat dari peningkatan hasil belajar untuk nilai siklus I mencapai 38,131 dan siklus II mencapai hingga 44,605. Untuk melihat persentase ketuntasan hasil belajar disiklus I mencapai $68,421 \%$ dan siklus II hingga mencapai $94,736 \%$.

\section{KESIMPULAN}

Berdasarkan hasil penelitian yang telah dilakukan dapat diambil suatu kesimpulan. Model pembelajaran inquiry dengan menggunakan metode eksperimen pada pokok bahasan pencemaran lingkungan dapat meningkatkan hasil belajar siswa kelas $X$ (Putri) di MA Bustanul Ulum Krai Yosowilangun tahun pelajaran 2016/2017.

\section{DAFTAR PUSTAKA}

Agus Suprijono, 2011:144. Pengertian penelitian tindakan kelas. Jakarta : PT. Bumi Aksara.

Anton, 2012. Pengertian dan macam pencemaran lingkungan.

http://www.sarjanaku.com/2012/06/pen cemaran-lingkungan-pengertianmacam.html.

Bruner, 1998. Pengertian hasil belajar. jakarta: Rineka Cipta.

Diah, 2012. Model pembelajaran inquiry. Jakarta: Tim Prestasi Pustaka.
Djamarah, 2002, Pengertian metode eksperimen. http:/ / www.eureka pendidikan.com/2014/10/pengertian-

Eureka, 2014. Pengertian dan peranan metode eksperimen. http://www.eureka pendidikan.com/2014/10/pengertiandan-peranan-metode experiment.html.

Maslow, 1994:59-62. Prestasi belajar. Jakarta: Tim Prestasi Pustaka.

Mashud, 2008. Analisis Data. Jakarta: Tim Prestasi Pustaka.

M. Dalyono, 2005, Faktor-Faktor Yang Mempengaruhi Hasil Belajar. jakarta: Rineka Cipta.

Nana Sudjana, 2009, Pengertian hasil belajar. jakarta: Rineka Cipta.

Nasution, 1990. Prestasi belajar. Jakarta: Tim Prestasi Pustaka.

Ramyulis,2005 :205. Langkah-langkah metode eksperimen. http://www.eureka pendidikan.com/2014/10/pengertiandan-peranan-metode experiment.html.

Rusyan Maulidia, 2011. Kelebihan dan kelemahan metode eksperimen. http://www.eureka pendidikan.com/2014/10/pengertiandan-peranan-metode experiment.html.

Slameto.1995. Belajar dan faktor-faktor yang mempengaruhinya. jakarta: Rineka Cipta.

Sudjadi, Bagod, dan kawan-kawan, 2004, Biologi Sains Dalam Kehidupan kelas I SMA Semester Kedua, Penerbit Yudhistira Surabaya

Sudjana,N. 1990. Penelitian dan penilaian pendidikan. Bandung: PT. Sinar Baru. 
Suharsimi Arikunto.2013:138, Pengertian tindakan kelas : PT. Bumi Aksara: Jakarta

Suhardjono. 2008. Penelitian Tindakan Kelas Sebagai Kegiatan Pengembangan Profesi Guru: PT. Bumi Aksara: Jakarta.

Sringatin Baseri, 2007, Biologi, IA KTSP, Penerbit Mapan, Surabaya

Syamsuri, Istamar dan kawan-kawan 2004, biologi untuk SMA kelas $X$ semester 2, Penerbit Erlangga, Jakarta.

Triadi. 2011. Karakteristik metode eksperimen. http:/ / www.eureka pendidikan.com/2014/10/2pengertiandan-peranan-metode experiment.html. 